\title{
Effect of Terrain Characteristics on Soil Organic Carbon and Total Nitrogen Stocks in Soils of Herschel Island, Western Canadian Arctic
}

\author{
J. Obu, ${ }^{1 *}$ H. Lantuit, ${ }^{1,2}$ I. Myers-Smith, ${ }^{3}$ B. Heim,${ }^{1}$ J. Wolter ${ }^{1}$ and M. Fritz ${ }^{1}$ \\ 1 Alfred Wegener Institute Helmholtz Centre for Polar and Marine Research, Potsdam, Germany \\ ${ }^{2}$ University of Potsdam, Potsdam, Germany \\ ${ }^{3}$ University of Edinburgh, Edinburgh, UK
}

\begin{abstract}
Permafrost landscapes experience different disturbances and store large amounts of organic matter, which may become a source of greenhouse gases upon permafrost degradation. We analysed the influence of terrain and geomorphic disturbances (e.g. soil creep, active-layer detachment, gullying, thaw slumping, accumulation of fluvial deposits) on soil organic carbon (SOC) and total nitrogen (TN) storage using 11 permafrost cores from Herschel Island, western Canadian Arctic. Our results indicate a strong correlation between SOC storage and the topographic wetness index. Undisturbed sites stored the majority of SOC and TN in the upper $70 \mathrm{~cm}$ of soil. Sites characterised by mass wasting showed significant SOC depletion and soil compaction, whereas sites characterised by the accumulation of peat and fluvial deposits store SOC and TN along the whole core. We upscaled SOC and TN to estimate total stocks using the ecological units determined from vegetation composition, slope angle and the geomorphic disturbance regime. The ecological units were delineated with a supervised classification based on RapidEye multispectral satellite imagery and slope angle. Mean SOC and TN storage for the uppermost $1 \mathrm{~m}$ of soil on Herschel Island are $34.8 \mathrm{~kg} \mathrm{C} \mathrm{m}^{-2}$ and $3.4 \mathrm{~kg} \mathrm{~N} \mathrm{~m}^{-2}$, respectively. Copyright $\odot 2015 \mathrm{John}$ Wiley \& Sons, Ltd.
\end{abstract}

KEY WORDS: organic carbon; nitrogen; permafrost disturbance; mass movement; supervised classification; Canadian arctic

\section{INTRODUCTION}

Landscapes underlain by permafrost are favourable environments for organic matter accumulation (Hobbie et al., 2000). Annual ground temperatures below $0{ }^{\circ} \mathrm{C}$ coupled with impeded drainage result in low organic matter degradation rates and long-term carbon storage (Bockheim, 2007; Hugelius et al., 2014). Increased Arctic air and ground temperatures enhance permafrost thaw and deepen the active layer (Romanovsky et al., 2010). This warming could transform carbon sinks into sources (Schuur et al., 2009) and release old soil carbon into the atmosphere as carbon dioxide or methane (Zimov et al., 2006). Another important greenhouse gas is nitrous oxide, which can be produced by nitrification and denitrification of activated organic compounds (Ciais et al., 2014). Increased atmospheric concentrations of these greenhouse gases and further increases in air temperatures could lead to 'permafrost carbon feedback'

* Correspondence to: J. Obu, Alfred Wegener Institute Helmholtz Centre for Polar and Marine Research, Potsdam, Germany.

E-mail: jaroslav.obu@awi.de
(Schaefer et al., 2014). Nitrogen is also considered as a limiting nutrient in northern ecosystems (Shaver and Chapin, 1980) and plays an important role and carbon cycling (Harden et al., 2012). Organic carbon and nitrogen can also be released through coastal erosion and river discharge (Lantuit et al., 2012; Vonk et al., 2012), impacting aquatic and marine ecosystems (Jones et al., 2005; Frey et al., 2007).

Greenhouse gas and lateral organic carbon and nitrogen fluxes originating from thawed permafrost soil organic matter have not yet been incorporated into global climate projections (Kuhry et al., 2010; Schaefer et al., 2014). Their incorporation is hindered by uncertainties in the amount of soil carbon and nitrogen in a soil profile (Koven et al., 2013; Burke et al., 2013). Recent global estimates of soil organic carbon (SOC) stocks in permafrost areas range between 1100 and $1500 \mathrm{Pg}$, and around $472 \mathrm{Pg}$ for the $0-1 \mathrm{~m}$ depth only (Tarnocai et al., 2009; Hugelius et al., 2013a, 2014). There is no comparable circum-Arctic estimate for nitrogen stocks. Studies of SOC stocks in permafrost regions use a simple upscaling strategy, averaging values from individual pedons to landscape units (Hugelius and Kuhry, 2009;

Received 26 February 2015 Revised 14 September 2015
Accepted 30 September 2015 
Hugelius et al., 2010, 2011), geomorphic units (Ping et al., 2011; Zubrzycki et al., 2013), or units derived from the normalised difference vegetation index (NDVI) (Horwath Burnham and Sletten, 2010). In contrast to estimations of SOC stocks, regional studies of total nitrogen (TN) stocks in permafrost regions are scarce (Ping et al., 2011; Harden et al., 2012; Zubrzycki et al., 2013).

Disturbances such as fires, permafrost thaw and anthropogenic activities influence SOC and TN storage in permafrost landscapes (Harden et al., 2000; Turetsky et al., 2002; Myers-Smith et al., 2007; O'Donnell et al., 2011). Geomorphic disturbances can also influence SOC and TN storage. Mass wasting can result in material removal and the exposure of lower soil horizons to subaerial processes, which causes an altered soil moisture regime and permafrost degradation (Kokelj and Lewkowicz, 1999). Grosse et al. (2011) discussed the possible effect of active-layer detachments, thermal erosion gullies and retrogressive thaw slumps (RTSs) on permafrost degradation. Studies of the effect of slow mass wasting (e.g. solifluction) on SOC and TN are lacking. Geomorphic disturbance can, however, also lead to material accumulation, thereby increasing storage through riverine sedimentation (Zubrzycki et al., 2013) or peat accumulation (Botch et al., 1995). In our study, mass wasting is considered to encompass a wide range of processes, from slow solifluction and stream gullying to rapid active-layer detachments and retrogressive thaw slumping. In order to better estimate changes in carbon and nitrogen fluxes caused by permafrost disturbance and thaw, more accurate storage assessments and a better understanding of the role of geomorphic disturbances are required.

The present study addresses the knowledge gaps identified above by testing the hypotheses that: (1) terrain significantly influences SOC and TN storage on Herschel Island; and (2) mass wasting here significantly reduces SOC and TN storage. Our aim is to improve knowledge about processes affecting SOC and TN storage in permafrost environments. Our objectives are: (1) to compile a highresolution estimate of SOC and TN storage for Herschel Island (Yukon Territory, Canada), a location known for a diverse terrain and large number of mass movements (Lantuit and Pollard, 2008); and (2) to assess the influence of terrain and geomorphic disturbance on SOC and TN storage.

\section{STUDY AREA}

Herschel Island is located at $69^{\circ} 34^{\prime} \mathrm{N}$ and $138^{\circ} 55^{\prime} \mathrm{W}$ in the Beaufort Sea off the northwestern mainland Yukon coast (Canada), $60 \mathrm{~km}$ east of the Alaskan border. The island measures 13 x $15 \mathrm{~km}$ and covers an area of $110 \mathrm{~km}^{2}$ (Figure 1). The mean annual air temperature is $-9^{\circ} \mathrm{C}$ and daily averages rise above $5^{\circ} \mathrm{C}$ in July and August (Burn, 2012). Yearly precipitation is between 150 and $200 \mathrm{~mm}$. As a result of strong winds, snow is blown from higher ground and accumulates in snow beds in low-lying parts of the landscape (Burn, 2012). Herschel Island is a push moraine formed by the Laurentide Ice Sheet (Bouchard, 1974; Fritz et al., 2012). The island is made of unconsolidated and mostly fine-grained marine sediment and is characterised by abundant massive ice of glacial origin (Bouchard, 1974; Pollard, 1990; Fritz et al., 2011). Permafrost is continuous, with a mean annual ground temperature of $-8^{\circ} \mathrm{C}$ at the depth of zero amplitude depth at Collinson Head. Active-layer depths normally range between 40 and $60 \mathrm{~cm}$ depending on the topography (Burn and Zhang, 2009).

Herschel Island rises to a maximum height of $180 \mathrm{~m}$ asl. Its undulating topography is cut by numerous valleys and gullies. Gully walls often lack vegetation and are undergoing strong geomorphic disturbance. A number of gullies end in alluvial fans. Wet polygonal terrain is present on flatter ground and in enclosed depressions. Slopes are characterised by mass movements ranging from slow solifluction to rapid active-layer detachments (Figure 2). Beaches are characterised by high bluffs or spits. The coastline is often disturbed by RTSs that form because ground-ice-rich headwalls wear back laterally (Lantuit et al., 2012). Coasts experience high rates of erosion (Lantuit and Pollard, 2008).

Soils on Herschel Island were classified according to the Canadian system of soil classification (Canada Soil Survey Committee, 1978). Organic Cryosols predominate and other soil types are present only on beaches and spits which are not underlain by near-surface permafrost (Smith et al., 1989). The most typical subtypes are Turbic Cryosols, characterised by cryoturbation, and Static Cryosols, characterised by recent disturbance. Soils that are not underlain by permafrost are either Regosols or Brunisols (Smith et al., 1989). The general vegetation type on Herschel Island is lowland tundra (Myers-Smith et al., 2011). Smith et al. (1989) defined seven ecological units on Herschel Island (Table 1), based on the vegetation, soil characteristics and geomorphic disturbance.

\section{METHODS}

\section{Fieldwork and Sampling}

Study sites were selected to be representative of each of the ecological units (Table 1). We used these units as the basis for upscaling of SOC and TN content and site grouping according to geomorphic disturbance. The names of the units defined by Smith et al. (1989) are based on local landmarks or fauna. We adapted these unit names to landscape and terrain characteristics in order to enable comparison with units from other areas in the Arctic with similar characteristics.

In July 2013, we cored 12 locations (Table 2). At each location, a detailed terrain and vegetation survey was undertaken to characterise the ground surface. A pit was dug until the thaw depth was reached. Cores were drilled to a depth of $60-250 \mathrm{~cm}$ below the surface with a Snow, Ice and Permafrost Research Establishment permafrost-coring auger barrel drill (manufactured in Jon's Machine Shop, Fairbanks, 


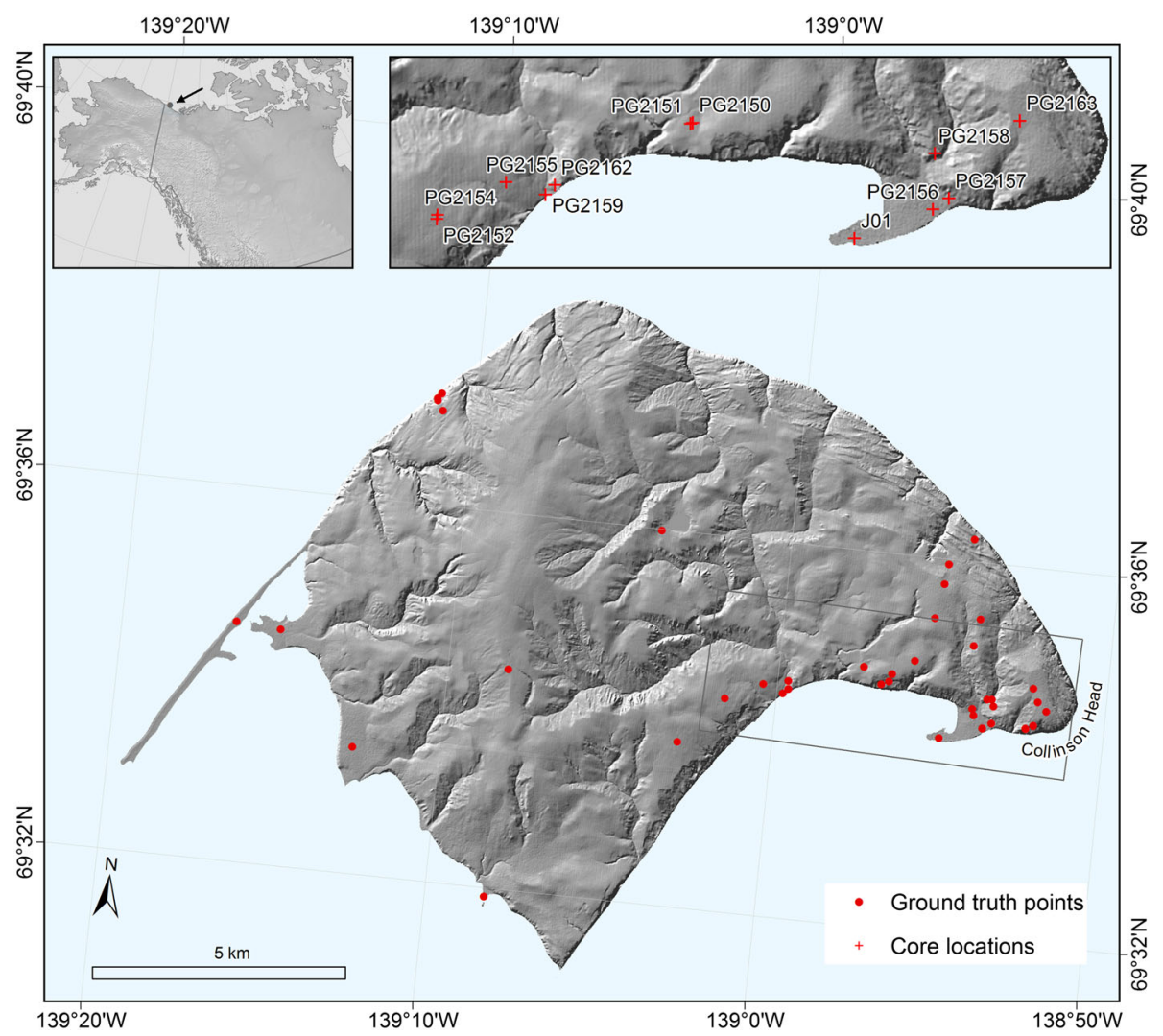

Figure 1 Overview map of Herschel Island with ground truth points used for supervised classification. The upper left panel shows the location of Herschel Island. The upper right panel, whose area is delineated by the rectangle in the lower main panel, shows the coring locations on Herschel Island. The cores are labelled as J01 and PG2150-PG2163. The terrain of Herschel Island is shown with shaded relief (grayscale underground). This figure is available in colour online at wileyonlinelibrary.com/journal/ppp

Alaska, USA) with an inner diameter of $7.5 \mathrm{~cm}$ and equipped with a Stihl BT 121 engine (Waiblingen, Germany). Where thaw depth exceeded $70 \mathrm{~cm}$, a pit was dug and no permafrost core was taken because of the difficulty of digging and setting up the coring equipment. We drilled at least one core in each ecological unit, obtaining ten cores and digging two pits. The uppermost metre of the pit or core was sampled every $10 \mathrm{~cm}$; below $1 \mathrm{~m}$ depth we sampled every $20 \mathrm{~cm}$. Sampling depths were adapted to visible changes in facies or cryostructure. We obtained $7.5 \times 7.5 \times 5 \mathrm{~cm}$ samples from the active layer. Permafrost core samples were $5 \mathrm{~cm}$ thick and $7.5 \mathrm{~cm}$ in diameter.

\section{Laboratory Analyses}

The 128 samples obtained were weighed to determine wet weight, freeze dried at $-20^{\circ} \mathrm{C}$ in a vacuum and reweighed to determine dry weight. They were then ground, mixed and milled for elementary analyses, and subsampled for further analyses. Samples were separately analysed for carbon and nitrogen content in an Elementar vario EL III and for total organic carbon (TOC) content using an Elementar vario MAX C manufactured by Elementar Analysensysteme $\mathrm{GmbH}$, Hanau, Germany.

\section{Ecological Unit Mapping}

Ecological units were mapped from remotely sensed imagery and a digital elevation model (DEM) using a supervised classification. The units were defined based on terrain properties, soil types and vegetation, and thus are suitable for the study of soil properties in relation to geomorphic processes. A cloud-free and almost snowpack-free RapidEye satellite acquisition on 15 August 2010 was selected to map the units. The RapidEye image is multispectral and has a horizontal resolution of around $6.5 \mathrm{~m}$ at nadir. The image was georeferenced based on ground control points taken from Lantuit and Pollard (2008) and orthorectified using a DEM derived from an IKONOS stereopair. The DEM itself was resampled from $2 \mathrm{~m}$ resolution to $6.5 \mathrm{~m}$ resolution with cubic convolution to fit to the resolution of the RapidEye image. Small artefacts (parallel stripes) were removed from the DEM data-set using a $4 \times 4$ round average filter. Preliminary results showed that SOC content correlates well with slope angle and for this reason it was added to the classification. The slope angle layer at $6.5 \mathrm{~m}$ resolution was calculated from the DEM. An atmospheric correction (atmospheric and topographic correction module in PCI Geomatica 2013) (Richter, 1996) was applied to the RapidEye image 

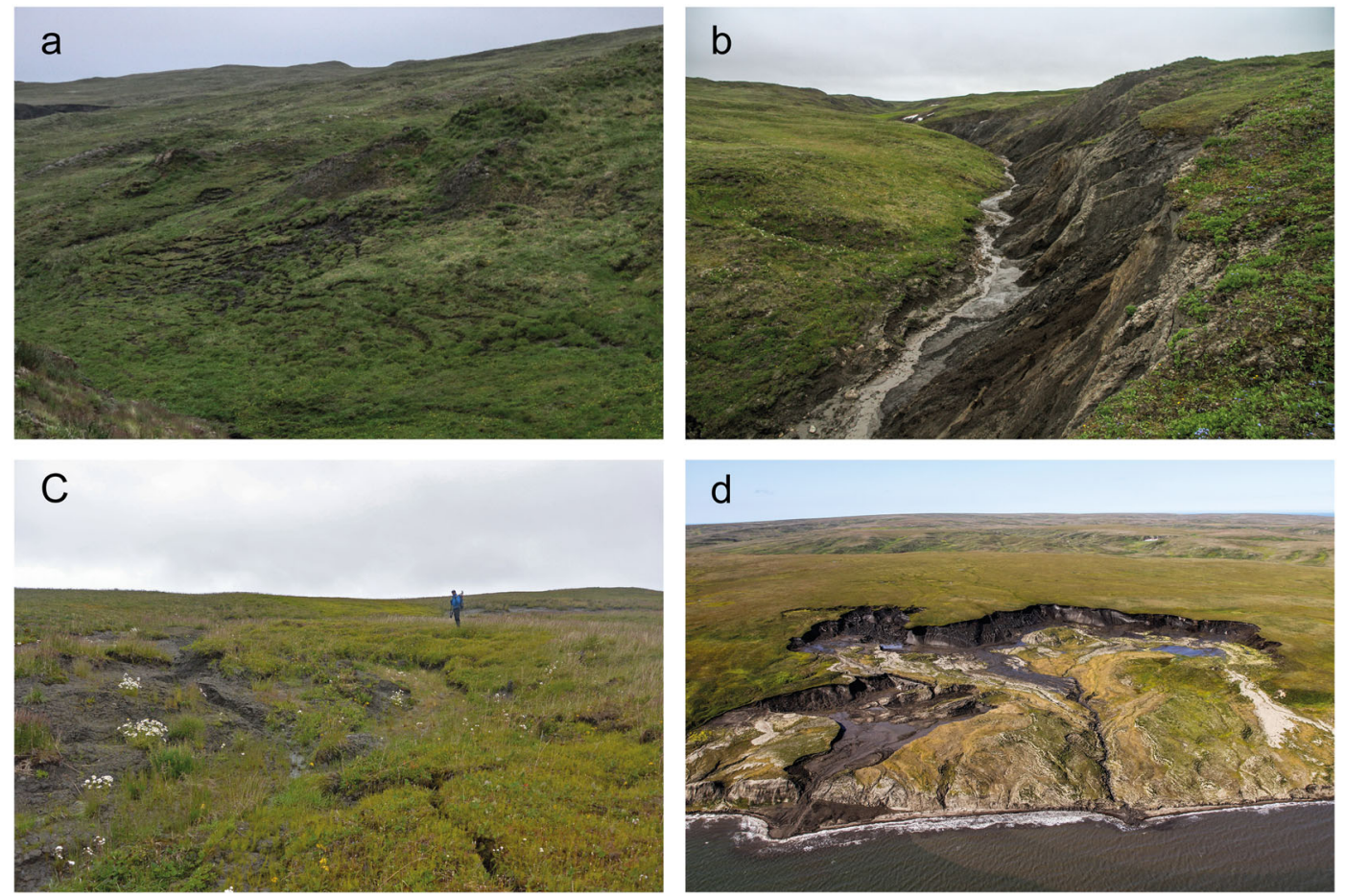

Figure 2 Examples of mass wasting on Herschel Island: (a) solifluction; (b) gullying; (c) active-layer detachment; and (d) retrogressive thaw slumping. This figure is available in colour online at wileyonlinelibrary.com/journal/ppp

to calculate the surface reflectance values and remove the effects of low sun angle and shading.

Areas surveyed in the field were used as training units for the supervised classification. The terrain was inspected visually for vegetation and terrain properties to correctly assign the sites to the ecological units. The area boundaries were mapped in the field with a handheld Garmin Etrex H GPS (Schaffhausen, Switzerland). We added additional areas that we delineated on the basis of satellite imagery for the areas that had been identified during helicopter surveys (spits, alluvial fans and polygons). In total, 21 areas were used as training units for the supervised classification. An additional training unit was added to identify water bodies and separate them from the classification results. A slope layer was added as a new input band to improve the classification results.

The maximum likelihood supervised classification of the RapidEye image and slope angle added as an additional layer was performed in Exelis ENVI 5.0 (Environment for Visualizing Images) (ENVI, 2008). The result was post-processed by sieving in ENVI and using a 4 x 4 circle majority filter and boundary-clean tools in ArcGIS 10.1 (ESRI, 2012) to remove isolated pixels and incorporate small unit areas into adjacent and prevalent units. The classification accuracy was assessed using ground truth points. We used coring locations and vegetation survey locations from the previous fieldwork of Myers-Smith et al. (2011). Additionally, we used ground truth points collected from other parts of the island by previous expeditions (e.g. Lantuit et al., 2012). Photographs and vegetation data collected at the survey sites during these expeditions were inspected and assigned to an ecological unit. A total of 40 ground truth points were collected to assess the classification accuracy (Figure 1).

\section{Upscaling of SOC and TN Contents}

SOC and TN contents were calculated using the gravimetric contents of TOC and TN in the samples. The dry bulk density was calculated using the dry weight and the volume of samples. Volumetric TOC and TN contents $\left(\mathrm{kg} \mathrm{C} \mathrm{m}^{-2}\right.$ and $\mathrm{kg} \mathrm{N} \mathrm{m}{ }^{-2}$, respectively) were then calculated for a $1 \mathrm{~cm}$ sample thickness $\left(\mathrm{cm} \mathrm{m}^{2}\right)$ using the following equations:

$$
\begin{gathered}
\mathrm{SOC}=\mathrm{cOC} \times \rho \\
\mathrm{TN}=\mathrm{cN} \times \rho
\end{gathered}
$$

where $\mathrm{cOC}$ and $\mathrm{cN}$ are the gravimetric contents of organic carbon and nitrogen, respectively, in the weight fraction and $\rho$ is the dry bulk density in $\mathrm{g} \mathrm{cm}^{-3}$. The coarse grain size fraction (particles $>2 \mathrm{~mm}$ ) was not included in the calculations because it was either absent or present in negligible amounts. SOC and TN contents from the samples were extrapolated to apply to adjacent parts of the core that were not sampled; extrapolation extended half of the distance to the next sample along the core. The total contents of SOC and TN (in $\mathrm{kg} \mathrm{C} \mathrm{m}^{-2}$ and $\mathrm{kg} \mathrm{N} \mathrm{m}^{-2}$, respectively) in a core were calculated by summing the content of each centimetre 
Geomorphic Disturbance, SOC and TN

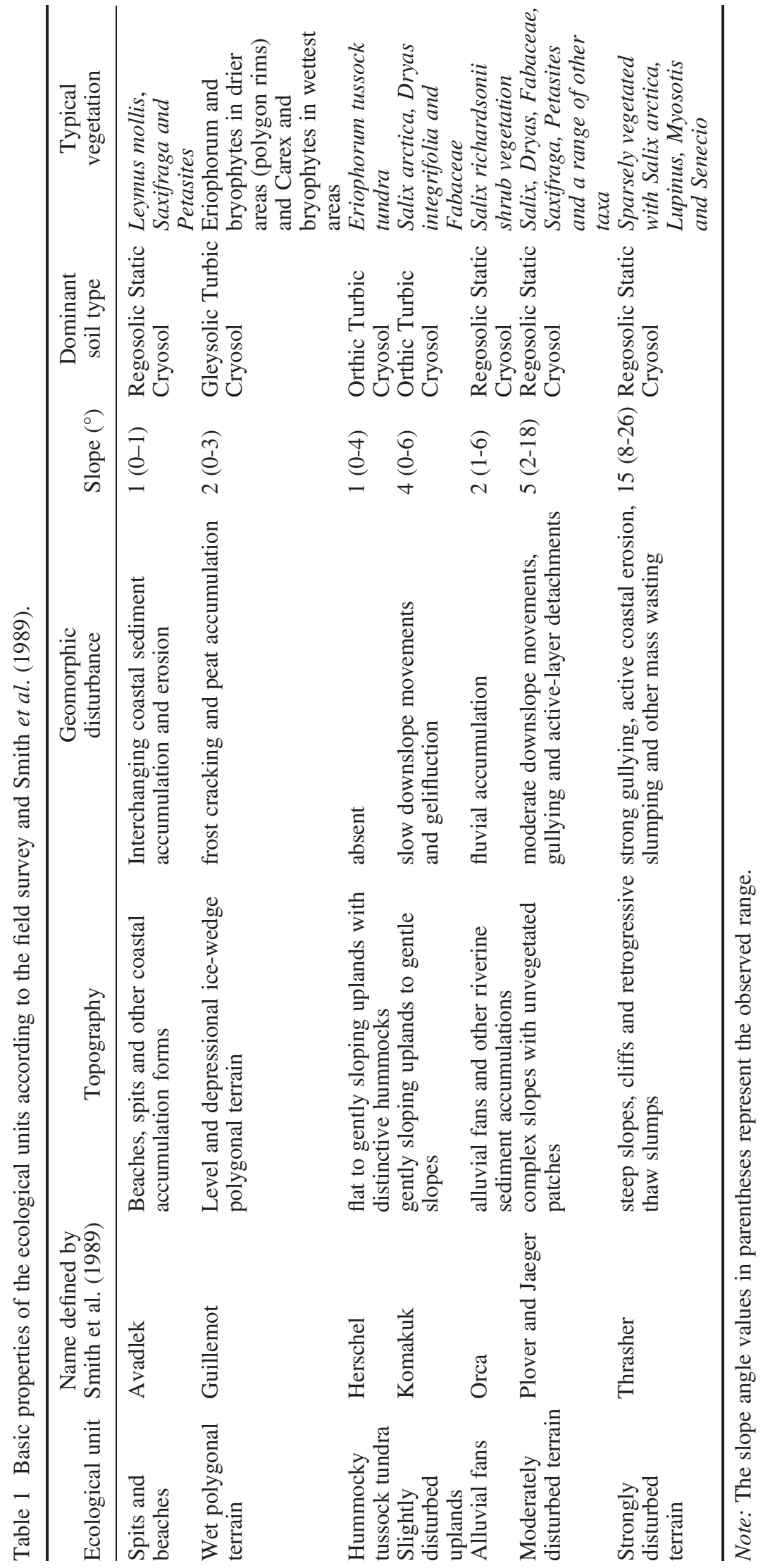




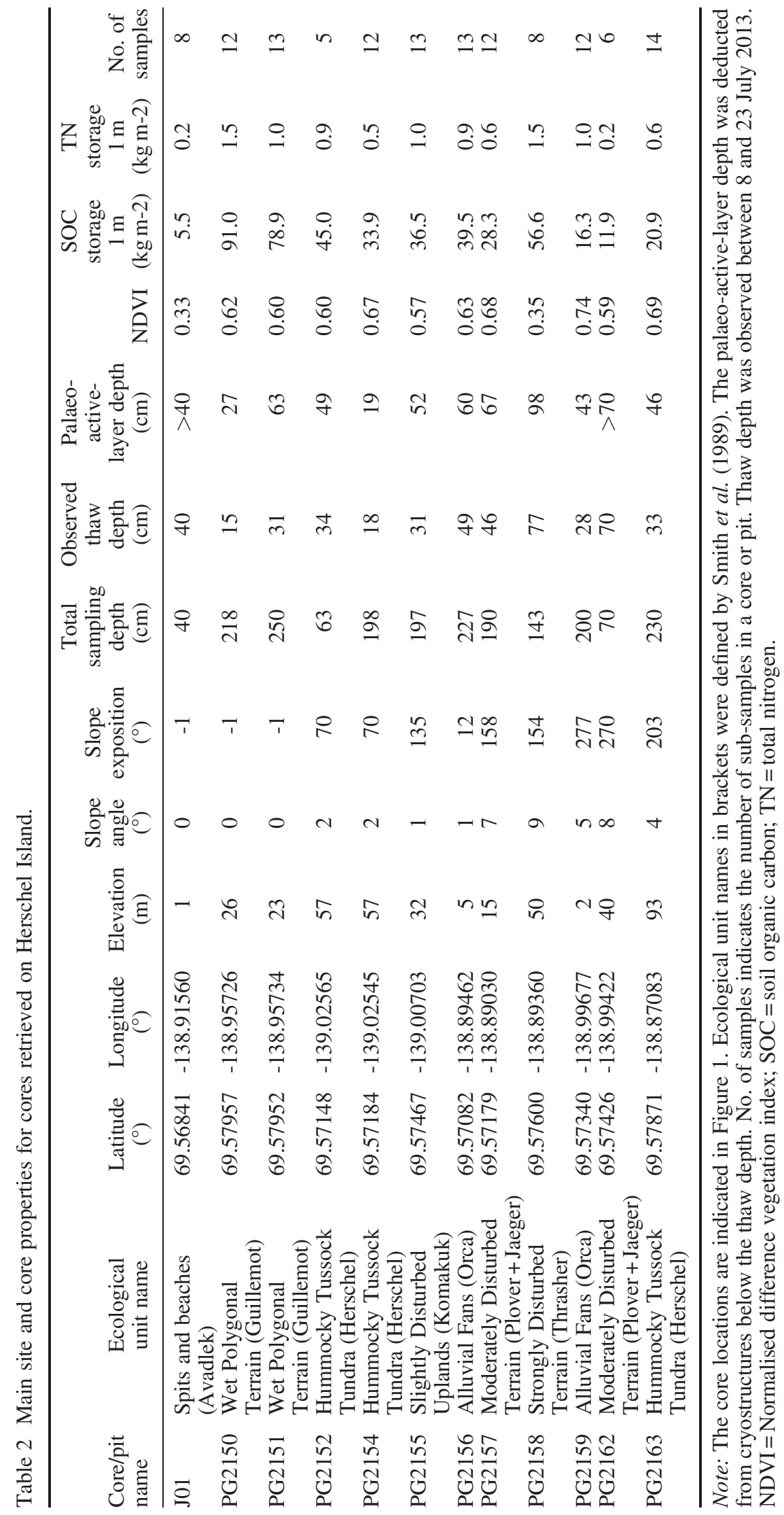


of the core. The values were calculated for three different depth ranges: $0-30 \mathrm{~cm}$ (SOC $0-30 \mathrm{~cm}$ and $\mathrm{TN} 0-30 \mathrm{~cm}$ ), 0-1 $\mathrm{m}$ (SOC 0-100 cm and TN 0-100 cm) and 0-2 $\mathrm{m}$ (SOC 0-200 cm and TN 0-200 cm). In shorter cores, the value of the lowermost sample was extrapolated downwards. Cores and pits that did not exceed $1 \mathrm{~m}$ were J01, PG2152 and PG2162. Core PG2158 reached $143 \mathrm{~cm}$. Extrapolation of SOC and TN for 0-2 $\mathrm{m}$ is less certain for these cores.

Core values were averaged across the cores for ecological units with more than one core; otherwise, the value of the single core was assigned to the ecological unit. These values were multiplied by the cell area and the numbers of cells from the classification to calculate stocks of SOC and TN for the ecological units and for the whole island. Carbon to nitrogen $(\mathrm{C} / \mathrm{N})$ ratios for the ecological units were calculated from upscaled unit-specific SOC and TN values. We used the SOC and TN content of the uppermost metre of soil in further statistical analyses, which is standard in SOC stock quantifications (e.g. Tarnocai et al., 2009).

\section{Assessing the Role of Terrain on Site SOC and TN Storage}

We assessed the role of terrain on SOC and TN storage on Herschel Island by correlating them to environmental variables such as slope, soil moisture, the topographic wetness index (TWI), elevation and the NDVI. Geomorphic disturbance is not a linearly measurable variable because it encompasses both accumulation and mass wasting. For this reason, we divided the sites into three groups according to the prevalent geomorphic processes (Table 1): (1) undisturbed sites (showing little or no evidence for accumulation or mass wasting: slightly disturbed uplands and hummocky tussock tundra units); (2) mass-wasting sites (evidence of recent or past downslope movements: strongly and moderately disturbed terrain units); and (3) accumulation sites (fluvial and peat accumulation: alluvial fans and wet polygonal terrain units).

We related slope angle, elevation, moisture content, the TWI and the NDVI to SOC and TN storage in the uppermost $1 \mathrm{~m}$ of soil using univariate statistics. Slope angle and elevation were measured on site. The TWI and NDVI site values were extracted from raster layers (Table 2). The
TWI was calculated as defined by Beven and Kirkby (1979) with upslope area calculated based on the D8 flow direction algorithm. The TWI was calculated from the same DEM used for supervised classification. The NDVI is a remote sensingderived proxy indicative of vegetation greenness and was calculated from the red and near-infrared bands of RapidEye imagery. The gravimetric soil moisture content was calculated from sample wet and dry mass on a wet soil basis and upscaled to cores using the same procedure as for SOC and TN contents. Slope angle, the degree of disturbance and elevation were measured in the field.

The Shapiro-Wilk test was used to test the normality of distributions. Pearson's correlation coefficients were calculated and linear regression analysis was used to calculate $\mathrm{R}$-squared values in order to estimate the amount of variance within SOC and TN that is explained by the environmental variables. p-Values were corrected with a 'false discovery rate correction' to account for any autocorrelation effects. Differences between geomorphic disturbance groups were tested with a Student's t-test. All statistical analyses were calculated using $\mathrm{R}$ software (R Core Team, 2014) (version 3.0.1). The pit from the spits and beaches unit was omitted from the correlation analysis because it is strongly influenced by marine processes that are not a subject of our study.

\section{RESULTS}

\section{Relation Between Geomorphic Disturbance and Site SOC and TN Storage}

Slope angle, the TWI and moisture content were significantly correlated with SOC $0-100 \mathrm{~cm}$ (Tables S1 and S2; Figure 3). The strongest correlation was found between the TWI and SOC $0-100 \mathrm{~cm}(r=0.79, p=0.004)$. Soil moisture content was also strongly positively correlated with SOC $0-100 \mathrm{~cm}(\mathrm{r}=0.69, \mathrm{p}=0.020)$. Slope angle was strongly negatively correlated with SOC $0-100 \mathrm{~cm}$ $(\mathrm{r}=-0.68, \mathrm{p}=0.023)$. Corrected $\mathrm{p}$-values of significant correlations remained within the 95 per cent confidence interval. Elevation $(r=-0.14, p=0.690)$ and the NDVI $(\mathrm{r}=0.23, \mathrm{p}=0.630)$ were not significantly correlated with
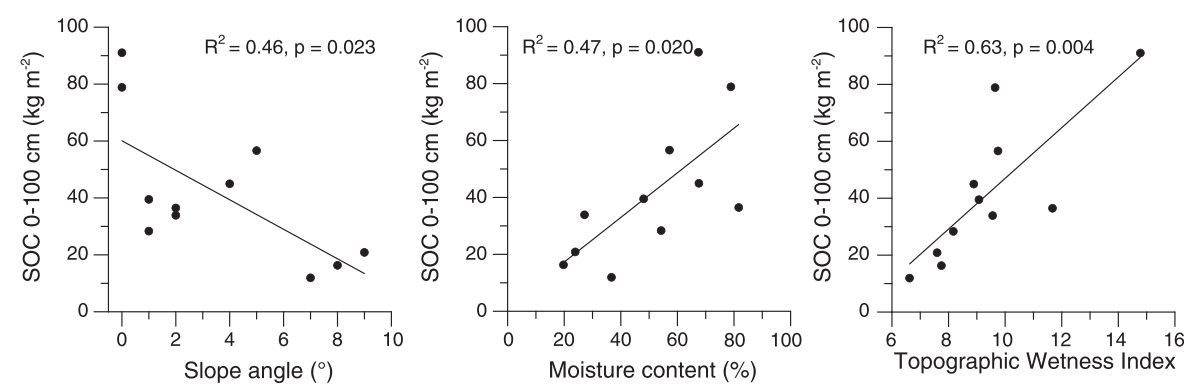

Figure 3 SOC $0-100 \mathrm{~cm}$ values plotted against slope angle, moisture content and the topographic wetness index with added linear trend line. SOC $=$ Soil organic carbon. 
SOC $0-100 \mathrm{~cm}$. We found no significant correlation of any of the studied variables with TN $0-100 \mathrm{~cm}$.

The comparison of means for each geomorphic disturbance group showed that SOC $0-100 \mathrm{~cm}$ in the masswasting group differs significantly from the undisturbed $(p=0.002)$ and accumulation groups $(p=0.04)$ (Figure 4). Group means of SOC $0-100 \mathrm{~cm}$ do not differ significantly between the accumulation and undisturbed groups $(\mathrm{p}=0.17)$. Group means of TN $0-100 \mathrm{~cm}$ are not significantly different (within 95\% confidence interval) between the geomorphic disturbance groups.

Down-core trend comparison showed that the majority of SOC and TN in undisturbed sites was stored in the upper $70 \mathrm{~cm}$ of the soil (Figure 5). Sites characterised by mass wasting showed low SOC contents in the upper profile and very high dry bulk densities below $50 \mathrm{~cm}$ depth. Sites undergoing peat and riverine accumulation showed a more homogeneous down-core distribution of SOC and TN storage.

\section{Supervised Classification}

According to our classification of the ecological units (Table 3; Figure 6), the slightly disturbed uplands unit occupies the largest area (32\%) of the island, followed by the hummocky tussock tundra (25\%) and the moderately disturbed terrain $(22 \%)$ units. The strongly disturbed terrain unit occupies 11 per cent and the wet polygonal terrain unit occupies 8 per cent. Spits and beaches and alluvial fans units each occupy 1 per cent of the total area.

The comparison of our ecological classification and ground truth points showed an overall 75 per cent classification accuracy (Table 3) and a kappa index of 0.70. The ecological units for which all ground truth points matched the classification output were spits and beaches, wet polygonal terrain and strongly disturbed terrain. One mismatch each occurred for the hummocky tussock tundra, alluvial fans and moderately disturbed terrain units. Two points out of nine of the slightly disturbed uplands unit were correctly classified. Ground truth points from this unit were close to the unit boundary, which could explain the lack of classification accuracy.

\section{SOC and TN Storage on Herschel Island}

The mean storage of SOC $0-100 \mathrm{~cm}$ and TN $0-100 \mathrm{~cm}$ for the entire island is $34.8 \mathrm{~kg} \mathrm{C} \mathrm{m}^{-2}$ and $3.4 \mathrm{~kg} \mathrm{~N} \mathrm{~m}^{-2}$, respectively (Table 4). The highest SOC value was assigned to the wet polygonal terrain unit, which contains $85 \mathrm{~kg} \mathrm{C} \mathrm{m}^{-2}$ in the uppermost $1 \mathrm{~m}$ of soil. The hummocky tussock tundra, slightly disturbed uplands and alluvial fans units had SOC $0-100 \mathrm{~cm}$ of around $40 \mathrm{~kg} \mathrm{C} \mathrm{m}$. Slightly lower SOC values were found in the strongly disturbed terrain and moderately disturbed terrain units. The spits and beaches unit had the lowest SOC value of $5.5 \mathrm{~kg} \mathrm{C} \mathrm{m}^{-2}$.

The TN storage generally followed SOC storage patterns, but with smaller differences. TN storage was high in wet polygonal terrain and hummocky tussock tundra (TN $0-100 \mathrm{~cm}$ was 4.6 and $4.0 \mathrm{~kg} \mathrm{~N} \mathrm{~m}^{-2}$, respectively), lower in disturbed units (TN $0-100 \mathrm{~cm}_{2} .0-3.7 \mathrm{~kg} \mathrm{~N} \mathrm{~m}^{-2}$ ) and lowest in spits and beaches (Figures 7 and 8). The $\mathrm{C} / \mathrm{N}$ ratio values were around 10 to 15 , except for the spits and beaches unit, which had a higher $\mathrm{C} / \mathrm{N}$ ratio.

Our estimates indicate that there are $3.9 \mathrm{Tg}$ of SOC and $0.4 \mathrm{Tg}$ of $\mathrm{TN}$ in the uppermost $1 \mathrm{~m}$ of soil on Herschel Island. The slightly disturbed uplands unit had the highest SOC and TN stocks. The spits and beaches unit had the lowest SOC and TN stocks. High amounts of SOC and TN were also found in the hummocky tussock tundra, wet polygonal terrain and moderately disturbed terrain units. Low amounts of SOC and TN were found in the alluvial fans and spits and beaches units, mostly because of their relatively small spatial extents. The spatial distribution of TN $0-100 \mathrm{~cm}$ stocks mostly followed the patterns in SOC stocks.

\section{DISCUSSION}

Our results based on 11 cores and site data showed an important effect of terrain characteristics on SOC
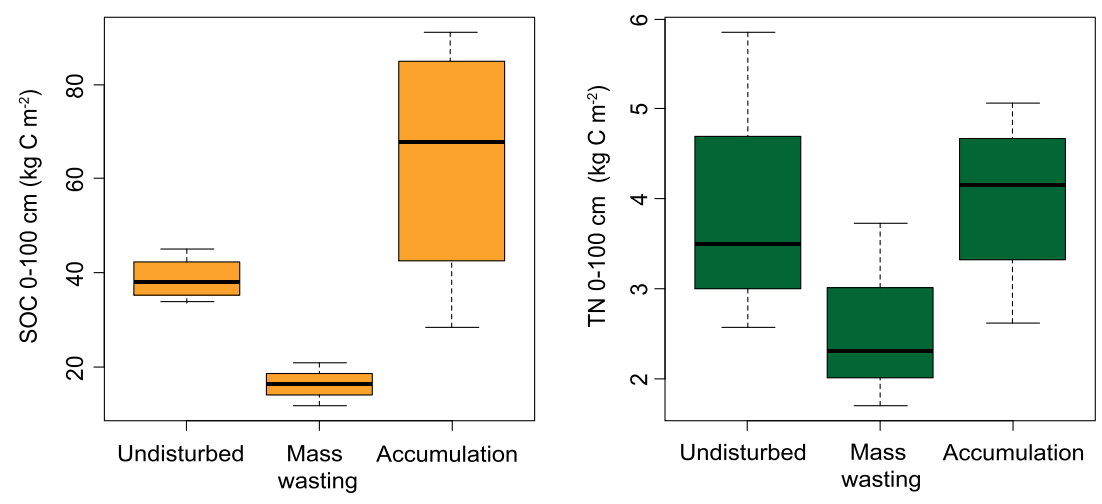

Figure 4 Boxplots of core SOC 0-100 $\mathrm{cm}$ and TN 0-100 cm storage grouped by geomorphic disturbance. Grouping of sites is described in the subsection: Assessing the Role of Terrain on Site SOC and TN Storage. SOC = Soil organic carbon; TN = total nitrogen. This figure is available in colour online at wileyonlinelibrary.com/journal/ppp 


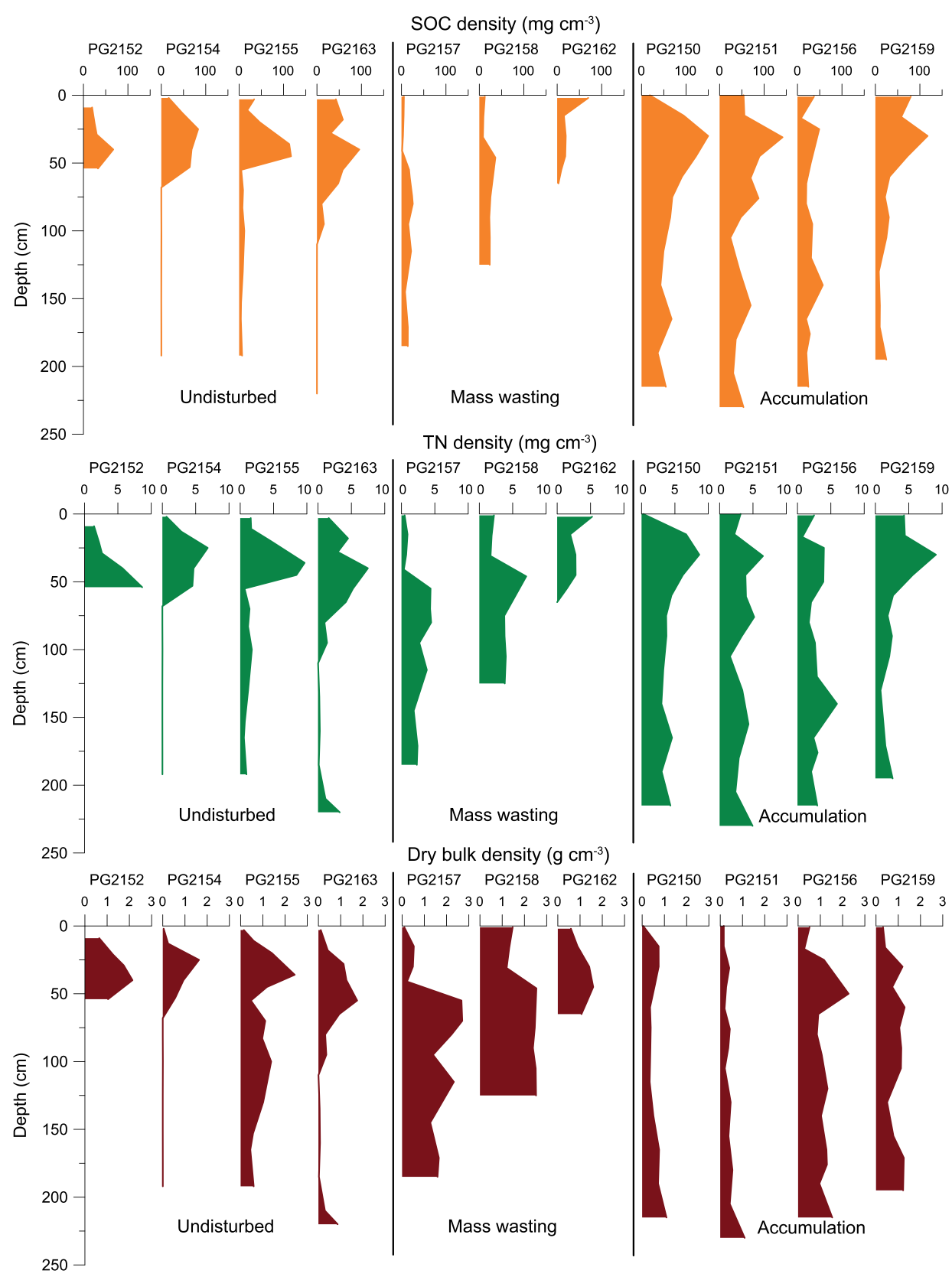

Figure 5 Down-core trends for SOC density, TN density and dry bulk density. Cores are grouped according to geomorphic disturbance. Cores PG2154 and PG2163 included ice- wedge ice which is indicated by low dry bulk density in deeper soil horizons. SOC = Soil organic carbon; TN = total nitrogen. This figure is available in colour online at wileyonlinelibrary.com/journal/ppp

storage. The majority of SOC $0-100 \mathrm{~cm}$ is explained by the TWI, which reflects the influence of a catenary slope position and slope characteristics. Sites that are visually affected by mass wasting show significant depletion of SOC storage. We estimate the mean storage of SOC and $\mathrm{TN}$ in the uppermost $1 \mathrm{~m}$ of soil on Herschel Island to be $34.8 \mathrm{~kg} \mathrm{C} \mathrm{m}^{-2}$ and $3.4 \mathrm{~kg} \mathrm{~N} \mathrm{~m}^{-2}$, respectively, with total stocks in the uppermost $1 \mathrm{~m}$ of soil to be $3.9 \mathrm{Tg} \mathrm{C}$ and $0.4 \mathrm{Tg} \mathrm{N}$. Such high carbon and nitrogen storage on Herschel Island is comparable to estimates reported for other Arctic regions.

\section{Effects of Terrain Characteristics on SOC and TN Storage}

The strong positive correlations between the TWI, slope angle and SOC 0-100 cm indicate that terrain has an important influence on SOC storage on Herschel Island. Slope angle affects soil drainage and soil moisture content, which further affects net primary production and decomposition (Birkeland, 1984). The TWI is calculated from local upslope area drainage and slope angle and is often used to quantify topographic control on hydrological processes 
Table 3 Contingency table of the classification accuracy between the observed (ground truth points) and predicted (classification) ecological units.

\begin{tabular}{|c|c|c|c|c|c|c|c|c|c|}
\hline $\begin{array}{l}\text { Predicted } \backslash \\
\text { Observed }\end{array}$ & $\begin{array}{l}\text { Spits and } \\
\text { beaches }\end{array}$ & $\begin{array}{c}\text { Wet Polygonal } \\
\text { Terrain }\end{array}$ & $\begin{array}{c}\text { Hummocky } \\
\text { Tussock } \\
\text { Tundra }\end{array}$ & $\begin{array}{l}\text { Slightly } \\
\text { Disturbed } \\
\text { Uplands }\end{array}$ & $\begin{array}{l}\text { Alluvial } \\
\text { Fans }\end{array}$ & $\begin{array}{c}\text { Moderately } \\
\text { Disturbed } \\
\text { Terrain }\end{array}$ & $\begin{array}{c}\text { Strongly } \\
\text { Disturbed } \\
\text { Terrain }\end{array}$ & Total & $\begin{array}{c}\text { User's } \\
\text { accuracy } \\
(\%)\end{array}$ \\
\hline Spits and beaches & 3 & 0 & 0 & 0 & 0 & 0 & 0 & 3 & 100.0 \\
\hline Wet Polygonal Terrain & 0 & 3 & 0 & 0 & 0 & 0 & 0 & 3 & 100.0 \\
\hline Hummocky Tussock Tundra & 0 & 0 & 7 & 3 & 0 & 0 & 0 & 10 & 70.0 \\
\hline Slightly Disturbed Uplands & 0 & 0 & 1 & 2 & 0 & 0 & 0 & 3 & 66.7 \\
\hline Alluvial Fans & 0 & 0 & 0 & 0 & 4 & 0 & 0 & 4 & 100.0 \\
\hline Moderately Disturbed Terrain & 0 & 0 & 0 & 2 & 1 & 7 & 0 & 10 & 70.0 \\
\hline Strongly Disturbed Terrain & 0 & 0 & 0 & 2 & 0 & 1 & 4 & 7 & 57.1 \\
\hline Producer's accuracy (\%) & 100.0 & 100.0 & 87.5 & 22.2 & 80.0 & 87.5 & 100.0 & & 75.0 \\
\hline
\end{tabular}

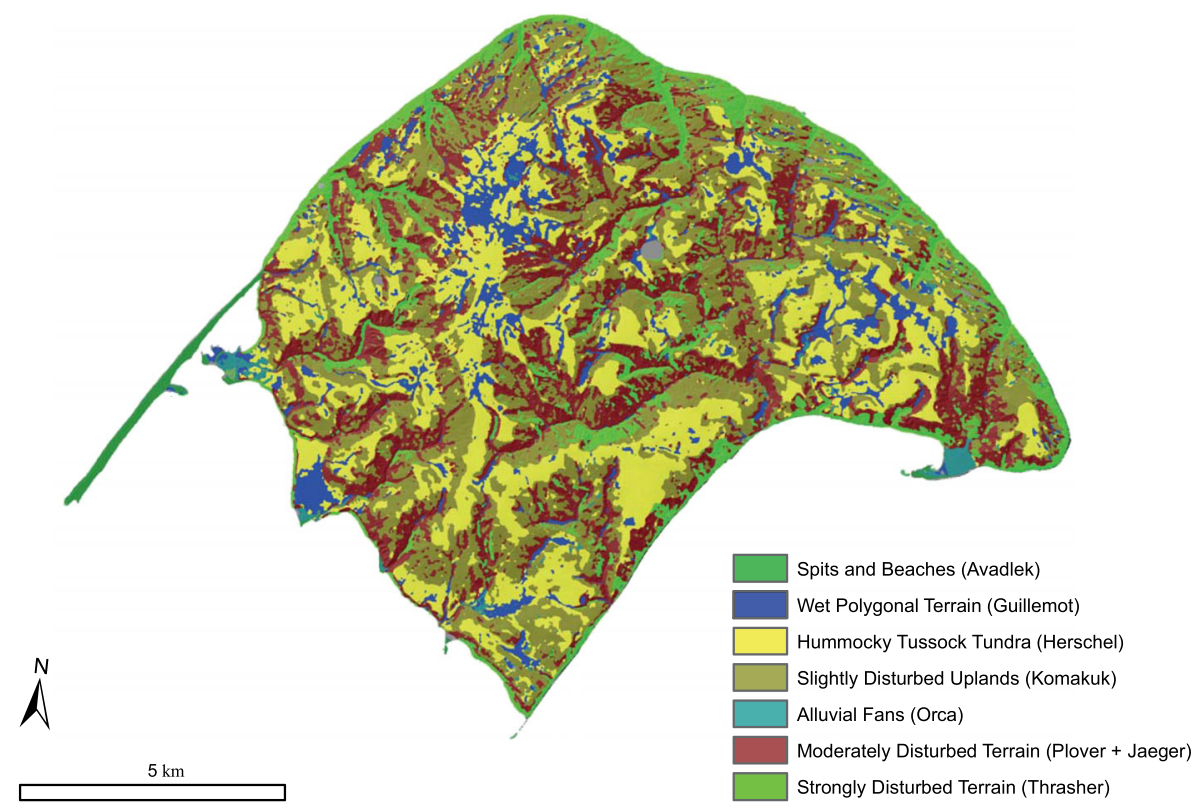

Figure 6 Ecological units on Herschel Island. The map is the post-processed output of supervised classification. These units were used for upscaling soil organic carbon and total nitrogen. This figure is available in colour online at wileyonlinelibrary.com/journal/ppp

and to predict soil organic matter distribution (Sørensen et al., 2006; Pei et al., 2010). Thus, the strong correlation between the TWI and SOC $0-100 \mathrm{~cm}\left(\mathrm{R}^{2}=0.63\right)$ indicates that the majority of SOC $0-100 \mathrm{~cm}$ variability is explained by hydrological conditions related to a catenary position and slope characteristics. Ground ice in permafrost, which was included in our moisture content calculation, may explain the weaker correlation between site-measured soil moisture and SOC $0-100 \mathrm{~cm}$ than expected because of the strong correlation between the TWI and SOC 0-100 cm.

Hydrological conditions also control the water content in the active layer, and increased porewater pressures may cause mass wasting (Matsuoka, 2001; Harris et al., 2008; Lewkowicz and Harris, 2005). Slope angle affects not only soil drainage, but also the intensity of mass wasting (Williams and Smith, 1989). For this reason, the part of SOC $0-100 \mathrm{~cm}$ variation that is explained by slope angle and soil moisture can also be attributed to mass wasting. Comparison between geomorphic disturbance groups revealed that sites with observed mass wasting contained significantly lower amounts of SOC $0-100 \mathrm{~cm}$ than undisturbed and accumulation sites (Figure 4). These groups included sites showing evidence of active or past mass wasting with various possible movement depths (from a few top centimetres to the whole active layer). Lantuit et al. (2012) analysed the active layer in stabilised RTS areas and undisturbed areas and showed that mass wasting can alter the soil moisture regime and consequently SOC storage.

The difference between geomorphic disturbance groups was also well reflected in down-core trends of SOC, TN and dry bulk density (Figure 5). High bulk density in masswasting sites indicates that the material had been compacted by mass-wasting processes, which has also been observed by Lantuit et al. (2012) on RTSs. In two of the mass-wasting 
Table 4 SOC and TN storage and $\mathrm{C} / \mathrm{N}$ ratios for different depth ranges on Herschel Island.

\begin{tabular}{|c|c|c|c|c|c|c|c|c|c|c|}
\hline $\begin{array}{l}\text { Ecological } \\
\text { unit }\end{array}$ & $\begin{array}{c}\text { Area } \\
(\mathrm{km} 2)\end{array}$ & $\begin{array}{c}\text { SOC } \\
\text { storage } \\
0-30 \mathrm{~cm} \\
(\mathrm{~kg} \mathrm{~m}-2)\end{array}$ & $\begin{array}{c}\text { SOC } \\
\text { storage } \\
0-100 \mathrm{~cm} \\
(\mathrm{~kg} \mathrm{~m}-2)\end{array}$ & $\begin{array}{c}\text { SOC } \\
\text { storage } \\
0-200 \mathrm{~cm} \\
(\mathrm{~kg} \mathrm{~m}-2)\end{array}$ & $\begin{array}{c}\mathrm{TN} \\
\text { storage } \\
0-30 \mathrm{~cm} \\
(\mathrm{~kg} \mathrm{~m}-2)\end{array}$ & $\begin{array}{c}\mathrm{TN} \\
\text { storage } \\
0-100 \mathrm{~cm} \\
(\mathrm{~kg} \mathrm{~m}-2)\end{array}$ & $\begin{array}{c}\mathrm{TN} \\
\text { storage } \\
0-200 \mathrm{~cm} \\
(\mathrm{~kg} \mathrm{~m}-2)\end{array}$ & $\begin{array}{c}\mathrm{C} / \mathrm{N} \\
\text { ratio } \\
0-30 \mathrm{~cm}\end{array}$ & $\begin{array}{c}\mathrm{C} / \mathrm{N} \\
\text { ratio } \\
0-100 \mathrm{~cm}\end{array}$ & $\begin{array}{c}\mathrm{C} / \mathrm{N} \\
\text { ratio } \\
0-200 \mathrm{~cm}\end{array}$ \\
\hline Spits and beaches & 1.1 & 5.5 & 5.5 & 5.5 & 0.2 & 0.2 & 0.2 & 24.6 & 24.6 & 24.6 \\
\hline Wet Polygonal Terrain & 8.6 & 22.8 & 84.9 & 132.1 & 1.3 & 4.6 & 7.8 & 18.2 & 18.6 & 16.8 \\
\hline Hummocky Tussock Tundra & 28.2 & 11.9 & 38.4 & 49.6 & 0.8 & 4.0 & 6.9 & 14.4 & 9.6 & 7.1 \\
\hline Slightly Disturbed Uplands & 35.0 & 10.6 & 39.5 & 46.5 & 0.9 & 3.4 & 4.5 & 12.1 & 11.5 & 10.4 \\
\hline Alluvial Fans & 1.3 & 15.5 & 42.5 & 66.0 & 1.1 & 3.4 & 5.9 & 14.2 & 12.3 & 11.2 \\
\hline Moderately Disturbed Terrain & 24.1 & 5.8 & 14.1 & 22.7 & 0.6 & 2.0 & 3.3 & 9.9 & 7.0 & 6.9 \\
\hline Strongly Disturbed Terrain & 12.6 & 3.0 & 20.9 & 44.3 & 0.6 & 3.7 & 7.6 & 5.2 & 5.6 & 5.9 \\
\hline Herschel Island & 110.9 & 10.0 & 34.8 & 48.3 & 0.8 & 3.4 & 5.4 & 12.6 & 10.4 & 8.9 \\
\hline
\end{tabular}

$\mathrm{SOC}=$ Soil organic carbon; $\mathrm{TN}=$ total nitrogen; $\mathrm{C} / \mathrm{N}=$ carbon to nitrogen.

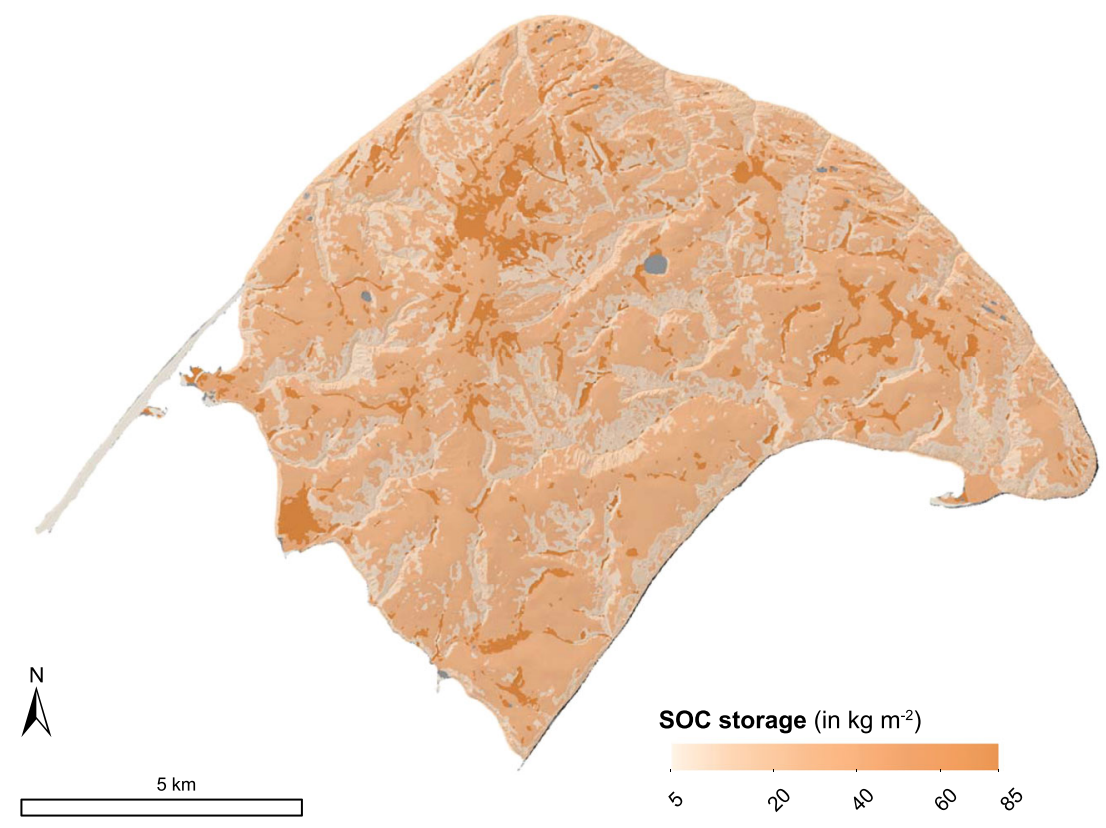

Figure 7 Map of SOC storage on Herschel Island for the uppermost metre of the soil. This map is the result of upscaling SOC $0-100 \mathrm{~cm}$ values to the ecological units in Figure 6. SOC $=$ Soil organic carbon. This figure is available in colour online at wileyonlinelibrary.com/journal/ppp

sites (PG2157 and PG2158), we found particularly low SOC storage in the upper $50 \mathrm{~cm}$. This might indicate that mass movements such as solifluction and active-layer detachment have decreased SOC storage in these sites. Slightly higher SOC storage deeper in the core could have been caused by compaction. Very small amounts of SOC and TN in the lower parts (below $70 \mathrm{~cm}$ ) of the cores from undisturbed sites were likely due to dilution effects in ice-rich ground.

Mass wasting may decrease SOC storage by material displacement and the exposure of lower layers to aeration and increased microbial activity (Pautler et al., 2010), causing organic matter decomposition and carbon degradation (Koven et al., 2011). Pizano et al. (2014) attributed onequarter of storage loss to aerobic decomposition in material displaced by RTS activity. Mass movements that remove soil cause permafrost thaw and may deepen the active layer. Leaching of particulate organic carbon also has the potential to decrease SOC storage. Woods et al. (2011) demonstrated that dissolved organic carbon delivered from watersheds with slope disturbances is more labile than dissolved organic carbon from undisturbed watersheds. Lamoureux and Lafrenière (2014) demonstrated that slope disturbances can activate old particulate organic carbon from formerly undisturbed watersheds. Repeated mass wasting can also hinder plant growth and thus decrease the accumulation of organic matter.

The insignificant correlation between terrain variables and TN $0-100 \mathrm{~cm}$ could be the consequence of low nitrogen concentrations and low sample size or could indicate that TN storage is less influenced by terrain than SOC storage. The higher loss of carbon in comparison to nitrogen 
during organic material decomposition results in decreasing soil $\mathrm{C} / \mathrm{N}$ ratios with decomposition (Meyers, 1994; Kuhry and Vitt, 1996). C/N ratios for 0-100 cm (Table 4) show significantly lower $\mathrm{C} / \mathrm{N}$ ratios in sites characterised by mass wasting than in other sites. Down-core trends (Figure 5) show that mass-wasting sites have, in comparison with other sites, significantly lower SOC contents, whereas TN storage is comparable to other sites. This might indicate that mass wasting promotes decomposition and carbon loss, but has a reduced impact on nitrogen storage. Low $\mathrm{C} / \mathrm{N}$ ratios that we observed on Herschel Island can be explained by the presence of marine algae in organic matter (Meyers, 1994), which originates from the marine sediment that was glacially reworked. $\mathrm{C} / \mathrm{N}$ ratios below 9 in strongly and moderately disturbed terrain can be due to the abundance of this material exposed by mass wasting. Very low $\mathrm{C} / \mathrm{N}$ ratios could also result from measured inorganic nitrogen that could have been present in the samples.

Most of the variance in SOC $0-100 \mathrm{~cm}$ storage in our study was explained by the TWI. Nevertheless, geomorphic disturbances such as mass wasting have an important effect on soil properties and decrease SOC storage. The effect of mass wasting on SOC storage might increase in the future under a warming climate (Grosse et al., 2011) with increasing retrogressive thaw slumping (Lantz and Kokelj, 2008) and an increase in active-layer detachment activity (Lewkowicz and Harris, 2005). Continuous and slow mass wasting such as solifluction and soil creep can cause a significant relocation of material across the landscape (Lewkowicz and Clarke, 1998). The effect of this slow, continuous geomorphic disturbance on SOC and TN storage needs to be studied in detail because it is one of the most widespread processes of soil movement in periglacial environments
(French, 2013) and the area affected by such disturbances across the circumpolar Arctic is likely much larger than the limited area affected by active-layer detachments and RTSs (Grosse et al., 2011).

\section{Suitability of the Ecological Classification for SOC Upscaling}

Upscaling SOC to units derived from multispectral satellite imagery is a commonly used procedure in the analysis of Arctic landscapes. We found that slope angle is an important determinant of SOC for the diverse terrain of Herschel Island. Adding a slope angle layer to spectral bands of satellite imagery significantly improved the accuracy of our supervised classification of ecological units, and ultimately of SOC estimations. Horwath Burnham and Sletten (2010) used NDVI classes for SOC upscaling in the High Arctic of Greenland. The lack of correlation between the NDVI and SOC found in our study suggests that using the NDVI would not increase the accuracy of our SOC estimation. Adding information about the slope angle, soil moisture and catenary slope position could improve SOC storage estimates in areas with diverse terrain similar to that of Herschel Island.

Our classification accuracy is according to ground truth points' agreement (75\%) comparable to accuracies reported from other studies (78\%: Hugelius et al., 2012, and 77\%: Zubrzycki et al., 2013). The accuracy of our classification was high in spits and beaches, strongly disturbed terrain and wet polygonal terrain units. The units affected by disturbance were characterised by lower accuracy, which likely reflects the transitional nature of these classes

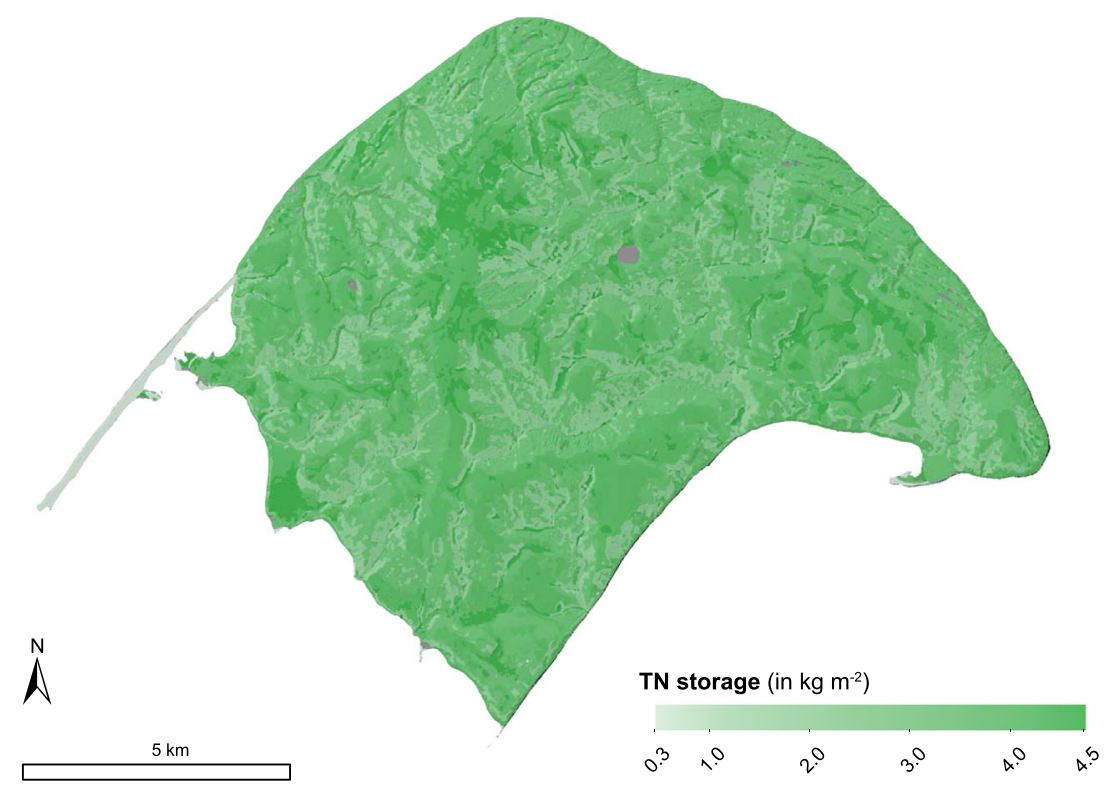

Figure 8 Map of TN storage on Herschel Island for the uppermost metre of soil. This map is the result of upscaling TN 0-100 $\mathrm{cm}$ values to the ecological units in Figure 6. TN = Total nitrogen. This figure is available in colour online at wileyonlinelibrary.com/journal/ppp 
Table 5 Comparison of SOC $0-100 \mathrm{~cm}$ storage in the ecological units in the present study to storage in comparable units from other studies.

\begin{tabular}{|c|c|c|c|c|c|}
\hline \multicolumn{2}{|l|}{ Herschel Island } & \multicolumn{4}{|c|}{ Comparable studies } \\
\hline Ecological unit & $\begin{array}{l}\text { SOC 0-100 cm } \\
\text { storage }(\mathrm{kg} \mathrm{m}-2)\end{array}$ & $\begin{array}{l}\text { Comparable unit in } \\
\text { other studies }\end{array}$ & Study area & $\begin{array}{l}\text { SOC 0-100 cm } \\
\text { storage }(\mathrm{kg} \mathrm{m}-2)\end{array}$ & Reference \\
\hline Wet polygonal terrain & 85 & Bog peatlands & $\begin{array}{l}\text { Central Canadian } \\
\text { Arctic }\end{array}$ & 80 & Hugelius et al. (2010) \\
\hline Hummocky tussock & 40 & Shrub tundra & Western Siberia & $10-40$ & Hugelius et al. (2011) \\
\hline & & & $\begin{array}{l}\text { Central Canadian } \\
\text { Arctic }\end{array}$ & $21-40$ & Hugelius et al. (2010) \\
\hline Alluvial fans & 42 & $\begin{array}{l}\text { Holocene floodplain } \\
\text { terrace }\end{array}$ & Lena River Delta & 30 & Zubrzycki et al. (2013) \\
\hline
\end{tabular}

$\mathrm{SOC}=$ Soil organic carbon.

observed in the field. These units often change gradually from one into another without a clearly established boundary.

\section{SOC and TN Storage and Stocks}

The SOC and TN storage found in our ecological units is comparable or higher than the storage reported from bog peatlands, shrub tundra and floodplain terraces in similar circum-Arctic studies (Table 5). There are no units in the literature comparable to our moderately and strongly disturbed units estimating SOC and TN storage, suggesting that the effect of mass wasting on SOC and TN storage was not included in existing storage estimations.

The mean SOC $0-100 \mathrm{~cm}$ storage on Herschel Island is estimated to be $34.8 \mathrm{~kg} \mathrm{C} \mathrm{m}^{-2}$. Hugelius et al. (2010) calculated a value of $33.8 \mathrm{~kg} \mathrm{C} \mathrm{m}^{-2}$ for the Tulemalu Lake area (central Canadian Arctic) and Hugelius et al. (2011) calculated one of $28.1 \mathrm{~kg} \mathrm{C} \mathrm{m}^{-2}$ for the Usa basin (European Russian Arctic). Zubrzycki et al. (2013) calculated $25.7 \mathrm{~kg} \mathrm{C} \mathrm{m}^{-2}$ for the Holocene part of the Lena River Delta. The same authors reported TN $0-100 \mathrm{~cm}$ storage in the Holocene part of the Lena River Delta (northern Siberia) to be $1.1 \mathrm{~kg} \mathrm{Nm}^{-2}$, which is three times lower than on Herschel Island $\left(3.4 \mathrm{~kg} \mathrm{~N} \mathrm{~m}^{-2}\right)$. In general, SOC storage on Herschel Island is similar to values reported in comparable environments elsewhere. In the Northern Circumpolar Soil Carbon Database, Hugelius et al. (2013b) reported $55.3 \mathrm{~kg} \mathrm{C} \mathrm{m}^{-2}$ of SOC $0-100 \mathrm{~cm}$ storage for the whole of Herschel Island, which overestimated the SOC $0-100 \mathrm{~cm}$ storage by 59 per cent.

The highest SOC and TN storage in the uppermost $1 \mathrm{~m}$ occurs in the wet polygonal terrain unit. This is largely because peat has probably been accumulating in the thermokarst depressions and flat valley bottoms since the beginning of the Holocene (Fritz et al., 2012). In these parts of the landscape, wet anoxic conditions favour the preservation of organic carbon and nitrogen (Hobbie et al., 2000). The second largest SOC and TN storage was observed in slightly disturbed or undisturbed ecological units with mineral soil that has undergone cryoturbation or has been influenced by the accumulation of fluvial sediment (Smith et al., 1989).

\section{CONCLUSIONS}

We found that terrain has an important influence on SOC storage on Herschel Island. The majority of variance in SOC storage (63\%) was explained by the TWI, an indication of a catenary position and slope characteristics. We also inferred that sites characterised by different geomorphic disturbances result in different SOC storage. Mass-wasting sites showed material compaction and decreased SOC storage, particularly in the upper $50 \mathrm{~cm}$. Increased mass wasting could lead to enhanced mobilisation of carbon and nitrogen stocks, which could have important impacts on both the terrestrial and marine components of this Arctic coastal ecosystem. While studies dealing with decreased SOC and TN in permafrost environments due to mass wasting that occurs as a single rapid event (e.g. RTS) exist, the importance of slow, continuous mass wasting such as solifluction has not yet been taken into account. We estimated average SOC $0-100 \mathrm{~cm}$ and TN $0-100 \mathrm{~cm}$ on Herschel Island to be $34.8 \mathrm{~kg} \mathrm{C} \mathrm{m}^{-2}$ and $3.4 \mathrm{~kg} \mathrm{~N} \mathrm{~m}^{-2}$, respectively. High-resolution studies such as ours will help to improve circum-Arctic storage estimates and projections of future fluxes of carbon and nitrogen with warming.

\section{ACKNOWLEDGEMENTS}

We would like to thank both anonymous reviewers for their constructive comments and suggestions, which helped to improve the manuscript. The study was financially supported by the Helmholtz Association through the COPER Young Investigators Group (VH-NG-801) and by the Alfred Wegener Institute Potsdam. Jaroslav Obu was financially supported by the Slovene Human Resources Development 
and Scholarship Fund. RapidEye imagery was provided by the German Aerospace Centre through the RapidEye Science Archive. We wish to thank the Aurora Research Institute, the Yukon Territorial Government and Yukon Parks (Herschel Island Qikiqtaruk Territorial Park) for administrational and logistical support, and the Inuvialuit people for the opportunity to conduct research on their traditional lands. We also thank Ute Kuschel, Lutz Schirrmeister and Jens Strauss, Alfred Wegener Institute Helmholtz Centre for Polar and Marine Research, Potsdam, Germany, for help with the sample processing and their useful suggestions.

\section{REFERENCES}

Beven KJ, Kirkby MJ. 1979. A physically based, variable contributing area model of basin hydrology/Un modèle à base physique de zone d'appel variable de l'hydrologie du bassin versant. Hydrological Sciences Journal 24: 43-69.

Birkeland PW. 1984. Soils and Geomorphology. Oxford University Press: Oxford, UK

Bockheim JG. 2007. Importance of cryoturbation in redistributing organic carbon in permafrost-affected soils. Soil Science Society of America Journal 71: 1335-1342.

Botch MS, Kobak KI, Vinson TS, Kolchugina TP. 1995. Carbon pools and accumulation in peatlands of the former Soviet Union. Global Biogeochemical Cycles 9: 37-46.

Bouchard M. 1974. Géologie des dépôts meubles de l'île Herschel, Territoire du Yukon. Montréal: Université de Montréal.

Burke EJ, Jones CD, Koven CD. 2013. Estimating the permafrost-carbon climate response in the CMIP5 climate models using a simplified approach. Journal of Climate 26: 4897-4909.

Burn CR. 2012. Climate. In Herschel Island Qikiqtaryuk A Natural and Cultural History. Burn CR (ed). University of Calgary Press: Calgary; 48-53.

Burn CR, Zhang Y. 2009. Permafrost and climate change at Herschel Island (Qikiqtaruq), Yukon Territory, Canada. Journal of Geophysical Research: Earth Surface 2003-2012 114, Issue F2.

Canada Soil Survey Committee. 1978. The Canadian System of Soil Classification. Research Branch, Canada Department of Agriculture.

Ciais P, Sabine C, Bala G, Bopp L, Brovkin V, Canadell J, Chhabra A, Ruth D, Galloway J, Heimann M, Jones C, Le Quéré C, Myneni RB, Piao S, Thornton P. 2014. Carbon and other biogeochemical cycles. In Climate Change 2013 - The Physical Science Basis, Intergovernmental Panel on Climate Change, Joussaume S, Penner J, Tangang F (eds). Cambridge University Press: Cambridge; 465-514.

ENVI. 2008. ENVI on-line software user's manual. ITT Visual Information Solutions.

ESRI. 2012. ArcGIS Desktop: Release 10.1. Redlands, CA. Environmental Systems Research Institute.
French HM. 2013. The Periglacial Environment. John Wiley \& Sons: Chichester.

Frey KE, McClelland JW, Holmes RM, Smith LC 2007. Impacts of climate warming and permafrost thaw on the riverine transport of nitrogen and phosphorus to the Kara Sea. Journal of Geophysical Research: Biogeosciences 112: G04S58. DOI: 10.1029/ 2006JG000369

Fritz M, Wetterich S, Meyer H, Schirrmeister L, Lantuit H, Pollard WH. 2011. Origin and characteristics of massive ground ice on Herschel Island (western Canadian Arctic) as revealed by stable water isotope and hydrochemical signatures. Permafrost and Periglacial Processes 22: 26-38: DOI:10.2136/sssaj2006.0414N.

Fritz M, Wetterich S, Schirrmeister L, Meyer H, Lantuit H, Preusser F, Pollard WH. 2012. Eastern Beringia and beyond: late Wisconsinan and Holocene landscape dynamics along the Yukon Coastal Plain, Canada. Palaeogeography, Palaeoclimatology, Palaeoecology 319: $28-45$.

Grosse G, Harden J, Turetsky M, McGuire AD, Camill P, Tarnocai C, Frolking S, Schuur EA, Jorgenson T, Marchenko S. 2011. Vulnerability of high-latitude soil organic carbon in North America to disturbance. Journal Of Geophysical Research: Biogeosciences 2005-2012 116: G00K06. DOI:10.1029/2010JG001507.

Harden JW, Trumbore SE, Stocks BJ, Hirsch A, Gower ST, O'Neill KP, Kasischke ES. 2000. The role of fire in the boreal carbon budget. Global Change Biology 6: 174-184.

Harden JW, Koven CD, Ping C-L, Hugelius G, David McGuire A, Camill P, Jorgenson T, Kuhry P, Michaelson GJ, O’Donnell JA. 2012. Field information links permafrost carbon to physical vulnerabilities of thawing. Geophysical Research Letters 39: L15704. DOI:10.1029/2012GL051958.

Harris C, Kern-Luetschg M, Murton J, Font M, Davies M, Smith F. 2008. Solifluction processes on permafrost and non-permafrost slopes: results of a large-scale laboratory simulation. Permafrost and Periglacial Processes 19: 359-378 DOI:10.1002/ppp.630.

Hobbie SE, Schimel JP, Trumbore SE, Randerson JR. 2000. Controls over carbon storage and turnover in high-latitude soils. Global Change Biology 6: 196-210.
Horwath Burnham J, Sletten RS. 2010. Spatial distribution of soil organic carbon in northwest Greenland and underestimates of high Arctic carbon stores. Global Biogeochemical Cycles 24: GB3012. DOI:10. 1029/2009GB003660.

Hugelius G, Kuhry P. 2009. Landscape partitioning and environmental gradient analyses of soil organic carbon in a permafrost environment. Global Biogeochemical Cycles 23: GB3006. DOI:10.1029/2008GB003419

Hugelius G, Kuhry P, Tarnocai C, Virtanen T. 2010. Soil organic carbon pools in a periglacial landscape: a case study from the central Canadian Arctic. Permafrost and Periglacial Processes 21: 16-29: DOI:10.1002/ppp.677.

Hugelius G, Virtanen T, Kaverin D, Pastukhov A, Rivkin F, Marchenko S, Romanovsky V, Kuhry P. 2011. High-resolution mapping of ecosystem carbon storage and potential effects of permafrost thaw in periglacial terrain, European Russian Arctic. Journal of Geophysical Research: Biogeosciences 2005-2012 116: G03024. DOI:10.1029/ 2010JG001606.

Hugelius G, Routh J, Kuhry P, Crill P. 2012. Mapping the degree of decomposition and thaw remobilization potential of soil organic matter in discontinuous permafrost terrain. Journal of Geophysical Research: Biogeosciences 2005-2012 117: G02030. DOI:10.1029/2011JG001873.

Hugelius G, Tarnocai C, Broll G, Canadell JG, Kuhry P, Swanson DK. 2013a. The Northern Circumpolar Soil Carbon Database: spatially distributed datasets of soil coverage and soil carbon storage in the northern permafrost regions. Earth System Science Data 5: 3-13.

Hugelius G, Bockheim JG, Camill P, Eberling B, Grosse G, Harden JW, Johnson K, Jorgenson T, Koven C, Kuhry P. 2013b. A new data set for estimating organic carbon storage to $3 \mathrm{~m}$ depth in soils of the northern circumpolar permafrost region. Earth System Science Data 5: 393-402.

Hugelius G, Strauss J, Zubrzycki S, Harden JW, Schuur E, Ping C-L, Schirrmeister L, Grosse G, Michaelson GJ, Koven CD. 2014. Improved estimates show large circumpolar stocks of permafrost carbon while quantifying substantial uncertainty 
ranges and identifying remaining data gaps. Biogeosciences 11: 4771-4822.

Jones JB, Petrone KC, Finlay JC, Hinzman LD, Bolton WR. 2005. Nitrogen loss from watersheds of interior Alaska underlain with discontinuous permafrost. Geophysical Research Letters 32: L02401. DOI:10. 1029/2004GL021734.

Kokelj SV, Lewkowicz AG. 1999. Salinization of permafrost terrain due to natural geomorphic disturbance, Fosheim Peninsula, Ellesmere Island. Arctic 52: 372-385.

Koven CD, Ringeval B, Friedlingstein P, Ciais P, Cadule P, Khvorostyanov D, Krinner G, Tarnocai C. 2011. Permafrost carbon-climate feedbacks accelerate global warming. Proceedings of the National Academy of Sciences 108: 14769-14774.

Koven CD, Riley WJ, Stern A. 2013. Analysis of permafrost thermal dynamics and response to climate change in the CMIP5 Earth System Models. Journal of Climate 26: 1877-1900.

Kuhry P, Vitt DH. 1996. Fossil carbon/ nitrogen ratios as a measure of peat decomposition. Ecology 77: 271-275.

Kuhry P, Dorrepaal E, Hugelius G, Schuur EAG, Tarnocai C. 2010. Potential remobilization of belowground permafrost carbon under future global warming. Permafrost and Periglacial Processes 21: 208-214: DOI:10.1002/ppp.684.

1Lamoureux SF, Lafrenière MJ. 2014. Seasonal fluxes and age of particulate organic carbon exported from Arctic catchments impacted by localized permafrost slope disturbances. Environmental Research Letters 9: 045002 .

Lantuit H, Pollard WH. 2008. Fifty years of coastal erosion and retrogressive thaw slump activity on Herschel Island, southern Beaufort Sea, Yukon Territory, Canada. Geomorphology 95: 84-102.

Lantuit H, Pollard WH, Couture N, Fritz M, Schirrmeister L, Meyer H, Hubberten H-W. 2012. Modern and late Holocene retrogressive thaw slump activity on the Yukon coastal plain and Herschel Island, Yukon Territory, Canada. Permafrost and Periglacial Processes 23: 39-51. DOI:10. 1002/ppp.1731.

Lantz TC, Kokelj SV. 2008. Increasing rates of retrogressive thaw slump activity in the Mackenzie Delta region, NWT, Canada. Geophysical Research Letters 35: L06502. DOI:10.1029/2007GL032433.

Lewkowicz AG, Clarke S. 1998. Late-summer solifluction and active layer depths, Fosheim Peninsula, Ellesmere Island, Canada. In Proceedings of the 7th International Conference on Permafrost. 23-27 June 1998, Yellowknife: Canada. Lewkowicz, AG, Allard $M(e d s)$. Centre d'études nordiques, Université Laval, Collection Nordicana No 55; 641-666.
Lewkowicz AG, Harris C. 2005. Frequency and magnitude of active-layer detachment failures in discontinuous and continuous permafrost, northern Canada. Permafrost and Periglacial Processes 16: 115-130. DOI:10.1002/ppp.522.

Matsuoka N. 2001. Solifluction rates, processes and landforms: a global review. Earth-Science Reviews 55: 107-134.

Meyers PA. 1994. Preservation of elemental and isotopic source identification of sedimentary organic matter. Chemical Geology 114: 289-302.

Michaelson GJ, Ping CL, Kimble JM. 1996. Carbon storage and distribution in tundra soils of Arctic Alaska, USA. Arctic and Alpine Research 28: 414-424.

Myers-Smith IH, McGuire AD, Harden JW, Chapin FS. 2007. Influence of disturbance on carbon exchange in a permafrost collapse and adjacent burned forest. Journal of Geophysical Research: Biogeosciences 2005-2012 112: G04017. DOI:10.1029/ 2007JG000423.

Myers-Smith IH, Hik DS, Kennedy C, Cooley D, Johnstone JF, Kenney AJ, Krebs CJ. 2011. Expansion of canopy-forming willows over the twentieth century on Herschel Island, Yukon Territory, Canada. Ambio 40: 610-623.

O'Donnell JA, Harden JW, McGuire AD, Romanovsky VE. 2011. Exploring the sensitivity of soil carbon dynamics to climate change, fire disturbance and permafrost thaw in a black spruce ecosystem. Biogeosciences 8: 1367-1382.

Pautler BG, Simpson AJ, Mcnally DJ, Lamoureux SF, Simpson MJ. 2010. Arctic permafrost active layer detachments stimulate microbial activity and degradation of soil organic matter. Environmental Science \& Technology 44: 4076-4082.

Pei T, Qin C-Z, Zhu A-X, Yang L, Luo M, Li B, Zhou C. 2010. Mapping soil organic matter using the topographic wetness index: a comparative study based on different flowdirection algorithms and kriging methods. Ecological Indicators 10: 610-619.

Ping C-L, Michaelson GJ, Guo L, Jorgenson MT, Kanevskiy M, Shur Y, Dou F, Liang J. 2011. Soil carbon and material fluxes across the eroding Alaska Beaufort Sea coastline. Journal of Geophysical Research: Biogeosciences 2005-2012 116: G02004. DOI:10.1029/2010JG001588.

Pizano C, Barón AF, Schuur EA, Crummer KG, Mack MC. 2014. Effects of thermoerosional disturbance on surface soil carbon and nitrogen dynamics in upland arctic tundra. Environmental Research Letters 9: 075006.

Pollard WH. 1990. The nature and origin of ground ice in the Herschel Island area,
Yukon Territory. In Proceedings, Fifth Canadian Permafrost Conference, Québec Centre d'etudes nordiques, Universitk Laval, Quebec, Collection Nordicana No 54; 23-30.

R Core Team. (2014). R: A language and environment for statistical computing $\mathrm{R}$ Foundation for Statistical Computing. Vienna, Austria. URL: http://www.R-project.org/.

Richter R. 1996. Atmospheric correction of satellite data with haze removal including a haze/clear transition region. Computers \& Geosciences 22: 675-681.

Romanovsky VE, Smith SL, Christiansen HH. 2010. Permafrost thermal state in the polar Northern Hemisphere during the international polar year 2007-2009: A synthesis. Permafrost and Periglacial Processes 21: 106-116.

Schaefer K, Lantuit H, Romanovsky VE, Schuur EA, Witt R. 2014. The impact of the permafrost carbon feedback on global climate. Environmental Research Letters 9: 085003 .

Schuur EA, Vogel JG, Crummer KG, Lee H, Sickman JO, Osterkamp TE. 2009. The effect of permafrost thaw on old carbon release and net carbon exchange from tundra. Nature 459: 556-559.

Shaver GR, Chapin FS III. 1980. Response to fertilization by various plant growth forms in an Alaskan tundra: nutrient accumulation and growth. Ecology 61: 662-675.

Smith CA, Kennedy C, Hargrave AE, McKenna KM. 1989. Soil and vegetation of Herschel Island. Research Branch, Agriculture Canada.

Sørensen R, Zinko U, Seibert J. 2006. On the calculation of the topographic wetness index: evaluation of different methods based on field observations. Hydrology and Earth System Sciences Discussions 10: 101-112.

Tarnocai C, Canadell JG, Schuur EAG, Kuhry P, Mazhitova G, Zimov S. 2009. Soil organic carbon pools in the northern circumpolar permafrost region. Global Biogeochemical Cycles 23: GB2023.

Turetsky M, Wieder K, Halsey L, Vitt D. 2002. Current disturbance and the diminishing peatland carbon sink. Geophysical Research Letters 29: 21-1-21-4.

Vonk JE, Sánchez-García L, van Dongen BE, Alling V, Kosmach D, Charkin A, Semiletov IP, Dudarev OV, Shakhova N, Roos P. 2012. Activation of old carbon by erosion of coastal and subsea permafrost in Arctic Siberia. Nature 489: 137-140.

Williams PJ, Smith MW. 1989. The Frozen Earth. Cambridge University Press: New York.

Woods GC, Simpson MJ, Pautler BG, Lamoureux SF, Lafrenière MJ, Simpson AJ. 2011. Evidence for the enhanced lability of dissolved organic matter 
J. Obu et al.

following permafrost slope disturbance in the Canadian High Arctic. Geochimica et Cosmochimica Acta 75: 7226-7241.

Zimov SA, Schuur EA, Chapin FS III. 2006. Permafrost and the global carbon budget. Science 312: 1612-1613.
Zubrzycki S, Kutzbach L, Grosse G, Desyatkin A, Pfeiffer EM. 2013. Organic carbon and total nitrogen stocks in soils of the Lena River Delta. Biogeosciences 10: 3507-3524.

\section{SUPPORTING INFORMATION}

Additional supporting information may be found in the online version of this article at the publisher's web site. 